\title{
Teaching NeuroImages: Ondine curse syndrome caused by dorsolateral medullary stroke
}

Erin Fiedler, DO, and Rick Gill, MD

Neurology ${ }^{\circledR}$ 2020;94:e1557-e1558. doi:10.1212/WNL.0000000000009219

Figure Dorsolateral medullary stroke in a 68-year-old man

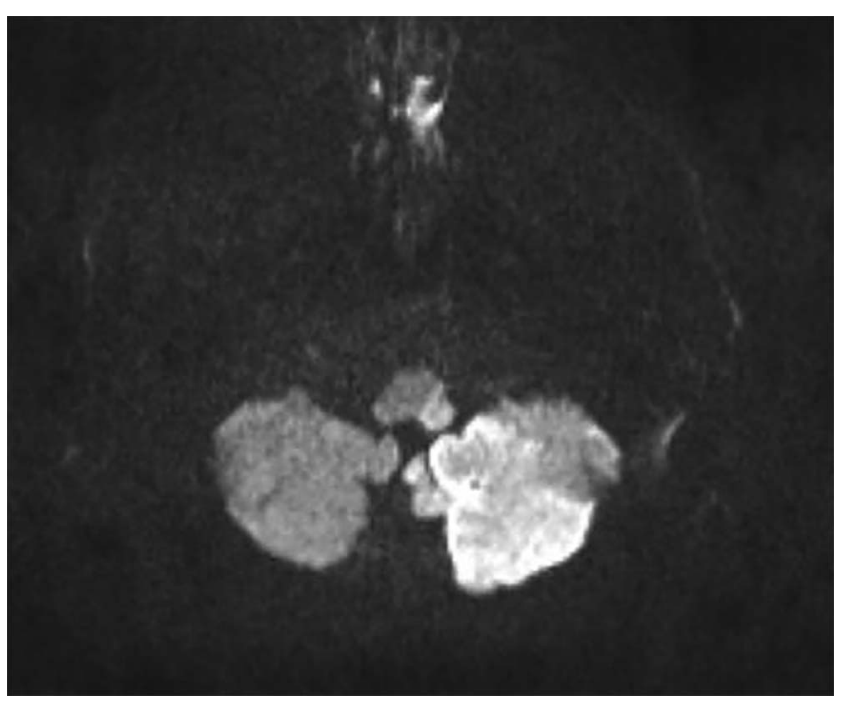

Diffusion-weighted imaging sequence on MRI demonstrates a left dorsolateral medullary infarction consistent with a posterior inferior cerebellar artery stroke. There is notable involvement of the left medullary reticular formation with sparing of the pyramidal tracts.

A 68-year-old man with an acute left dorsolateral medullary infarction (figure) had recurrent episodes of hypercarbic respiratory failure with sleep during hospitalization. While awake, the patient ventilated adequately, but when asleep, the patient developed a severe respiratory acidosis $\left(\mathrm{pH} 7.14, \mathrm{pCO}_{2}>107\right)$ and became unarousable. He was intubated and his mentation improved rapidly. Eventually, he had a tracheostomy placed and continued to have prolonged apneic episodes with sleep during spontaneous breathing trials. The patient did not have central sleep apnea prior to the stroke.

Respiration is classified as voluntary, limbic, automatic, and reflex. Two centers in the medulla control automatic respiration: the dorsal respiratory center and the medullary reticular formation. A unilateral lesion in the dorsolateral medulla can lead to cessation of automatic respiration due to disruption of decussating bulbospinal pathways leading to central alveolar hypoventilation or the Ondine curse syndrome. ${ }^{1}$

\section{Study funding}

No targeted funding reported.

\section{Disclosure}

The authors report no disclosures relevant to the manuscript. Go to Neurology.org/ $\mathrm{N}$ for full disclosures.

\author{
Correspondence \\ Dr. Fiedler \\ efiedlerdo@gmail.com
}

\section{MORE ONLINE}

$\rightarrow$ Teaching slides

links.lww.com/WNL/

B69

From the Department of Neurology, Loyola University Medical Center, Maywood, IL.

Go to Neurology.org/N for full disclosures. 


\section{Appendix Authors}

\begin{tabular}{lll}
\hline Name & Location & Contribution \\
\hline $\begin{array}{l}\text { Erin } \\
\text { Fodler, } \\
\text { Do }\end{array}$ & $\begin{array}{l}\text { Loyola University } \\
\text { Maywood }\end{array}$ & $\begin{array}{l}\text { Drafting/revising the manuscript, } \\
\text { data acquisition, study concept or } \\
\text { design, and analysis or interpretation } \\
\text { of data }\end{array}$ \\
\hline $\begin{array}{l}\text { Rick } \\
\text { Gill, MD }\end{array}$ & $\begin{array}{l}\text { Loyola University } \\
\text { Medical Center, }\end{array}$ & $\begin{array}{l}\text { Drafting/revising the manuscript, } \\
\text { data acquisition, study concept or } \\
\text { design, and analysis or interpretation } \\
\text { of data }\end{array}$ \\
& &
\end{tabular}

\section{Reference}

1. Polkey MI, Lyall RA, Moxhan J, et al. Respiratory aspects of neurological disease. J Neurol Neurosurg Psychiatry 1999;66:5-15. 


\section{Neurology}

\section{Teaching NeuroImages: Ondine curse syndrome caused by dorsolateral medullary stroke}

Erin Fiedler and Rick Gill

Neurology 2020;94;e1557-e1558 Published Online before print March 9, 2020

DOI 10.1212/WNL.0000000000009219

This information is current as of March 9, 2020

\section{Updated Information \&} Services

\section{References}

Subspecialty Collections

Permissions \& Licensing

Reprints including high resolution figures, can be found at: http://n.neurology.org/content/94/14/e1557.full

This article cites 1 articles, 1 of which you can access for free at: http://n.neurology.org/content/94/14/e1557.full\#ref-list-1

This article, along with others on similar topics, appears in the following collection(s):

\section{All Cerebrovascular disease/Stroke}

http://n.neurology.org/cgi/collection/all_cerebrovascular_disease_strok e

\section{All Sleep Disorders}

http://n.neurology.org/cgi/collection/all_sleep_disorders

\section{Critical care}

http://n.neurology.org/cgi/collection/critical_care DWI

http://n.neurology.org/cgi/collection/dwi

Information about reproducing this article in parts (figures,tables) or in its entirety can be found online at:

http://www.neurology.org/about/about_the_journal\#permissions

Information about ordering reprints can be found online:

http://n.neurology.org/subscribers/advertise

Neurology ${ }^{\circledR}$ is the official journal of the American Academy of Neurology. Published continuously since 1951, it is now a weekly with 48 issues per year. Copyright @ 2020 American Academy of Neurology. All rights reserved. Print ISSN: 0028-3878. Online ISSN: 1526-632X.

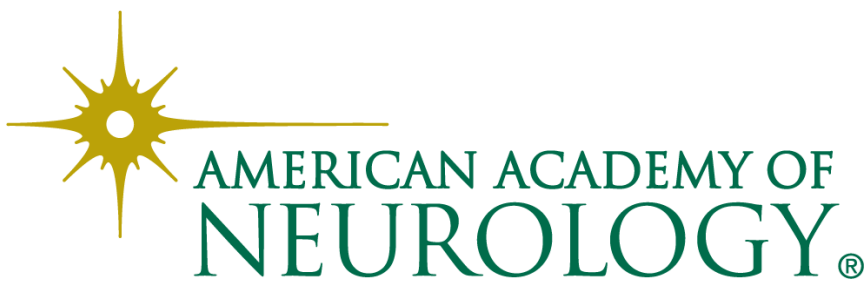

